\title{
NERVE GROWTH FACTOR-INDUCIBLE LARGE EXTERNAL (NILE) GLYCOPROTEIN: STUDIES OF A CENTRAL AND PERIPHERAL NEURONAL MARKER ${ }^{1}$
}

\author{
STEPHEN R. J. SALTON, CHRISTIANE RICHTER-LANDSBERG, ${ }^{2}$ LLOYD A. GREENE, AND \\ MICHAEL L. SHELANSKI ${ }^{3}$
}

Department of Pharmacology, New York University Medical Center, New York, New York 10016

Received April 30, 1982; Revised August 30, 1982; Accepted September 15, 1982

\begin{abstract}
The PC12 clone of pheochromocytoma cells undergoes neuronal differentiation in the presence of nerve growth factor (NGF). Concomitant with this is a significant induction in the incorporation of radiolabeled fucose or glucosamine into a 230,000-dalton cell surface glycoprotein named the NGFInducible Large External, or NILE, glycoprotein (GP) (McGuire, J. C., L. A. Greene, and A. V. Furano (1978) Cell 15: 357-365). In the current studies NILE GP was purified from PC12 cells using wheat germ agglutinin-agarose affinity chromatography and SDS-polyacrylamide gel electrophoresis (PAGE). Polyclonal antisera were raised against purified NILE GP and were found to selectively immunoprecipitate a single 230,000-dalton protein from detergent extracts of PC12 cells metabolically labeled with either $\left[{ }^{3} \mathrm{H}\right]$ fucose, $\left[{ }^{3} \mathrm{H}\right]$ glucosamine, or $\left[{ }^{35} \mathrm{~S}\right]$ methionine. These antisera stained the surfaces of PC12 cells by indirect immunofluorescence and were cytotoxic to PC12 cclls in the presence of complement. Limited treatment of PC12 cells with either trypsin or pronase produced a fucosylated 90,000-dalton immunoreactive fragment of NILE GP which remained in the membrane. Using quantitative immunoelectrophoresis, the action of NGF on NILE GP was shown to represent an increase in the amount of protein, rather than a selective increase in carbohydrate incorporation. Immunofluorescent staining of primary cell cultures and tissue whole mounts revealed that immunologically cross-reactive NILE GP appears to be expressed on the cell surfaces (somas and neurites) of most if not all peripheral and central neurons examined. Immunoprecipitation of radiolabeled cultures showed that the cross-reactive material had an apparent molecular weight by SDS-PAGE of 225,000 to 230,000 in the peripheral nervous system and 200,000 to 210,000 in the central nervous system. NILE-cross-reactive material was also found to a small extent on Schwann cell surfaces, but not at all on a variety of other cell types. These results suggest that immunoreactive NILE GP is distributed widely and selectively on neural cell surfaces.
\end{abstract}

The development and maturation of the nervous system are the result of complex and highly specific interactions among neural cells. Cell surface macromolecules, especially glycoproteins, are thought to play an important role in neural development (Moscona, 1974; Sidman,

\footnotetext{
${ }^{1}$ This research was supported by grants from the United States Public Health Service (NS15006, NS16036 and NS16839), the March of Dimes Birth Defects Foundation, and the McKnight Foundation. S. R. J. S. is a Medical Scientist Training Program Fellow (GM07308). We thank Dr. M. R. J. Salton and Mr. C. Urban for advice and assistance in running the rocket immunoelectrophoresis; Dr. I. Black and Mr. S. Erde for demonstrating iris and gut stretch preparations, respectively; and Drs. R. K. H. Liem and M. E. Hatten for helpful discussions.

${ }^{2}$ Current address: University of Bremen, Department of Biology, NW2, 28 Bremen 33, West Germany.

" To whom correspondence should be addressed.
}

1974; Barondes, 1976; Rutishauser and Edelman, 1980). The heterogeneity of cell types within the nervous system has complicated the investigation of neuronal cell surface molecules and has encouraged the search for simplified model systems in which differentiated neuronal properties are expressed. To this end, cell surface components, especially those which seem to be modulated by neuronal morphogenesis, have been examined in clonal cell lines and primary neuronal cultures (Akeson and Hsu, 1978; Littauer et al., 1980; Rohrer and Schachner, 1980; Lee et al., 1981).

One particular cell line, cloned from a rat adrenal medullary pheochromocytoma and designated PC12, has been extensively used to study neuronal differentiation (Greene and Tischler, 1976). PC12 cells grown in serumcontaining medium display many properties associated 
with normal adrenal chromaffin cells, including synthesis, storage, and release of catecholamines (Greene and Rein, $1977,1978)$ and the presence of chromaffin granules (Greene and Tischler, 1976). Addition of nerve growth factor (NGF) to PC12 cultures causes the cells to cease mitosis within several days and acquire many properties of sympathetic neurons including neurite outgrowth (Greene and Tischler, 1976), electrical excitability (Dichter et al., 1977), and increased acetylcholine sensitivity (Dichter et al., 1977). Among the advantages of this system is that large numbers of homogeneous cultures can be produced and that cells can be studied before and after treatment with NGF.

A comparison of the total cell proteins synthesized by PC12 cells before and after NGF treatment reveals no consistent qualitative and only a few quantitative changes (McGuire et al., 1978; Garrels and Schubert, 1979). Among these restricted quantitative changes is a marked induction in the incorporation of radiolabeled fucose or glucosamine into a 230,000-dalton glycoprolein (McGuire et al., 1978). In intact PC12 cells, this component can be removed by trypsin or labeled by lactoperoxidase-catalyzed iodination, implying that it is exposed on the cell surface (McGuire et al., 1978; Lee et al., 1981). On the basis of these properties, this macromolecule has been named the NGF-Inducible Large External, or NILE, glycoprotein. Heterologous antisera directed against whole PC12 cells have been found to recognize NILE glycoprotein (NILE GP) as well as several other cell surface glycoproteins. Studies with these polyspecific antisera have revealed that NILE GP is present on sympathetic neurons and in brain but not on a variety of other cell types (Lee et al., 1977, 1981). To further characterize the distribution of NILE GP within the nervous system, and ultimately to determine its function, we have purified NILE GP from PC12 cells and have raised a monospecific anti-NILE GP antiserum.

\section{Materials and Methods}

Cell culture. PC12 cells were cultured as previously described (Greene and Tischler, 1976) in complete medium $(85 \%$ Roswell Park Memorial Institute Medium (RPMI) $1610,10 \%$ horse serum, and 5\% fetal calf serum; $\mathrm{KC}$ Biologicals, Inc.) with or without $50 \mathrm{ng} / \mathrm{ml}$ of $2.5 \mathrm{~S}$ NGF (Mobley et al., 1976). Cells for immunofluorescence experiments were cultured on glass coverslips coated with mixtures of poly-L-lysine (Sigma Chemical Co.) and rat tail collagen (Bornstein, 1958). Collagen was diluted $1: 4$ with a solution of 50 to $100 \mu \mathrm{g} / \mathrm{ml}$ of poly-L-lysine and air dried on coverslips. Dissociated cell cultures of supcrior cervical ganglia (SCG) and dorsal root ganglia (DRG) were prepared from 2-day-old rats by methods described elsewhere (Lee et al., 1980b), except that the ganglia were incubated in a solution of $1 \mathrm{mg} / \mathrm{ml}$ of collagenase (Worthington) and $5 \mathrm{mg} / \mathrm{ml}$ of Dispase (Boehringer Mannheim). The cells were dissociated and maintained in complete medium with $50 \mathrm{ng} / \mathrm{ml}$ of NGF. NGF-deprived SCG cultures were dissociated and grown in NGF-unsupplemented medium containing a 1:100 dilution of rabbit anti-mouse 2.5 S NGF and were plated either on untreated or collagen-coated tissue culture dishes. Dissociated cell cultures of rat postnatal day 5 (P5) cerebellum, embryonic day 14 to $15(\mathrm{E} 14 / 15)$ cerebral cortex, and
E14/15 spinal cord were prepared by modification of previously described methods (Ransom et al., 1977; Dichter, 1978; Hatten, 1981). Tissue was removed, rinsed three times in CMF (a phosphate-buffered saline with glucose; Hatten and Sidman, 1978), and incubated in CMF with $1 \%$ trypsin, $0.1 \%$ DNase, and $6 \mathrm{mM} \mathrm{MgSO}_{4}$ for 5 min at $37^{\circ} \mathrm{C}$. After three washes with $\mathrm{CMF}$, the tissue was dissociated by mechanical trituration using narrowbore, fire-polished pasteur pipettes in Eagle's Basal Medium containing $0.5 \mathrm{mg} / \mathrm{ml}$ of DNase and $0.26 \%$ glucose. Dissociated cells were then pelleted by centrifugation, resuspended in complete medium containing 85\% Eagle's Basal Medium, $10 \%$ horse serum, and $5 \%$ fetal calf serum, and plated on cover slips and tissue culture dishes coated with collagen or collagen/polylysine. Primary cultures of rat skeletal and cardiac muscle were grown by previously published methods (Christian et al., 1978). Cell lines were grown either in complete RPMI medium (human neuroblastoma NB5; L. A. Greene, A. Rukenstein, and A. S. Tischler, unpublished) or in Dulbecco's modified Eagle's minimum essential medium supplemented with $10 \%$ horse serum and $5 \%$ fetal calf serum (murine N115 neuroblastoma, C6 glioma, and gerbil CCL-146 fibroma). All cells were grown in an atmosphere of $93 \%$ air $/ 7 \% \mathrm{CO}_{2}$ at $37^{\circ} \mathrm{C}$.

Labeling of cells. Glycoproteins were labeled by incubating the cells for $72 \mathrm{hr}$ in complete medium supplemented with 10 to $20 \mu \mathrm{Ci} / \mathrm{ml}$ of either $\mathrm{L}-\left[5,6{ }^{3} \mathrm{H}\right]$ fucose $\left(56.0 \mathrm{Ci} / \mathrm{mmol}\right.$; New England Nuclear) or $\mathrm{D}-\left[6{ }^{3} \mathrm{H}\right] \mathrm{glu}-$ cosamine hydrochloride $(22.6 \mathrm{Ci} / \mathrm{mmol}$; Amersham). Total cell proteins were labeled by incubation for $72 \mathrm{hr}$ in complete medium with $10 \mu \mathrm{Ci} / \mathrm{ml}$ of L- $\left[5,6-{ }^{3} \mathrm{H}(N)\right]$ leucine $(56.5 \mathrm{Ci} / \mathrm{mmol}$, New England Nuclear) or for $8 \mathrm{hr}$ in serum-free, methionine-deficient RPMI supplemented with $100 \mu \mathrm{Ci} / \mathrm{ml}$ of $\left.\mathrm{L}-{ }^{35}{ }^{35}\right]$ methionine $(1212.4 \mathrm{Ci} / \mathrm{mmol}$, Ncw England Nuclear). Primary cultures to be labeled were treated with cytosine arabinoside $(10 \mu \mathrm{M})$ for 24 to $48 \mathrm{hr}$ to eliminate dividing non-neuronal cells. The interval between the removal of cytosine arabinoside and the initiation of labeling was at least $24 \mathrm{hr}$.

Trypsinization. $\mathrm{PCl} 2$ cells, metabolically labeled with $\left[{ }^{3} \mathrm{H}\right]$ fucose, were incubated in serum-free RPMI containing $100 \mu \mathrm{g} / \mathrm{ml}$ of trypsin (Worthington, $221 \mathrm{units} / \mathrm{mg}$ ) for 15 min at $37^{\circ} \mathrm{C}$. Trypsinization was terminated by adding a 3 -fold excess of soybean trypsin inhibitor (Sigma). Control and trypsinized crude PC12 cell membranes were obtained by previously described methods (Lee et al., 1981). Crude membrane fractions were extracted in buffer A and aliquots were immunoprecipitated with anti-NILE GP as described below. Cells treated with $100 \mu \mathrm{g} / \mathrm{ml}$ of pronase (Calbiochem-Behring) were similarly processed.

Lectin affinity chromatography. $\mathrm{PC} 12$ cells were rinsed three times with PBS (phosphate-buffered saline; Dulbecco and Vogt, 1954) and extracted with $1 \%$ sodium deoxycholate in $10 \mathrm{~mm}$ Tris-Cl buffer, $\mathrm{pH} \mathrm{7.8,} \mathrm{for} 1 \mathrm{hr}$ at room temperature. The extract was then centrifuged at $27,000 \times g$ for $1 \mathrm{hr}$ at $4^{\circ} \mathrm{C}$. The supernatant was diluted 1:4 with $10 \mathrm{~mm}$ Tris-Cl buffer, $\mathrm{pH} 7.8$, and chromatographed, at room temperature, on a number of lectinagarose affinity columns (E-Y Labs). Flow rates of 2 to $4 \mathrm{ml} / \mathrm{min}$ were maintained. Detergent extracts were passed through the lectin columns once; multiple passages did not increase the fractional recovery of bound 
glycoproteins (i.e., trichloroacetic acid (TCA)-precipitable $\left[{ }^{3} \mathrm{H}\right]$ fucose cpm of eluted glycoproteins/TCA-precipitable $\left[^{3} \mathrm{H}\right\rceil$ fucose cpm of total glycoproteins loaded). Columns were rinsed with 5 bed volumes of $0.1 \%$ sodium deoxycholate in $10 \mathrm{~mm}$ Tris-Cl buffer, $\mathrm{pH}$ 7.8. Bound material was eluted with 2 volumes of the same buffer containing the appropriate hapten sugar (Sigma) at a concentration of $0.2 \mathrm{M}$.

The following agglutinins conjugated to agarose were screened for glycoprotein binding: Concanavalia Ensiformis (Con A), Dolichos Biflorus (DBA), Ricinus Communis (RCA), Ulex Europaeus (UEA), and Wheat Germ (WGA). PC12 cells were labeled with $\left[{ }^{3} \mathrm{H}\right]$ fucose, extracted with sodium deoxycholate, and chromatographed on the above lectin-agarose columns. Total recoveries (i.e., TCA-precipitable $\left[{ }^{3} \mathrm{H}\right]$ fucose cpm eluted plus unbound/total cpm loaded) averaged better than $80 \%$.

Antisera. Antisera were prepared in guinea pigs and rabbits. Excised gel fragments containing purified NILE GP (see "Results;" approximately 5 to $10 \mu \mathrm{g}$ /injection) were homogenized in Freund's adjuvant (complete for the first injection, incomplete for subsequent immunizations), and injected subcutaneously. The NILE GP isolated from approximately $15(100-\mathrm{mm})$ tissue culture dishes of NGF-treated PC12 cells was used for each immunization. After four additional weekly immunizations, animals were test bled and bled every 7 to 10 days thereafter. Antiserum titer was maintained by boosting every 3 to 4 weeks for 6 to 12 months.

Immunoprecipitation. For immunoprecipitation, labeled cells were extracted in buffer A (2.5\% Triton X-100, $0.1 \% \mathrm{SDS}, 190 \mathrm{~mm} \mathrm{NaCl}, 50 \mathrm{~mm}$ Tris-HCl, $6 \mathrm{~mm}$ EDTA, $2 \mathrm{~mm}$ phenylmethylsulfonyl fluoride (PMSF)) for $1 \mathrm{hr}$ at room temperature, and then centrifuged at $15,000 \mathrm{rpm}$ in a Brinkman 5412 microfuge for $30 \mathrm{~min}$ at $4^{\circ} \mathrm{C}$. Indirect immunoprecipitation, using protein A-Sepharose (Pharmacia), was carried out by modification of published procedures (Goldman and Blobel, 1978). Aliquots of 25, 000 to 50,000 TCA-precipitable $\left[{ }^{3} \mathrm{H}\right]$ fucose $\mathrm{cpm}$ or $10^{5}$ to $10^{6}$ TCA-precipitable $\left[{ }^{35}\right.$ S $]$ methionine cpm were diluted to a final volume of $200 \mu \mathrm{l}$ with buffer A. After addition of $1 \mu \mathrm{l}$ of antiserum, samples were gently agitated for 16 $\mathrm{hr}$ at $4^{\circ} \mathrm{C}$. Antigen-antibody complexes were precipitated by incubation with $5 \mathrm{mg}$ /aliquot of preswollen protein ASepharose ( $35 \mu \mathrm{g}$ of protein A/5 mg of protein A-Sepharose) for $2 \mathrm{hr}$ at room temperature. Protein A-Sepharose was washed with buffer $A$ and then boiled in sample buffer to elute the antigen-antibody complexes. The latter was electrophoresed on SDS gradient polyacrylamide gels as described below. In some experiments, anti-NILE GP was specifically absorbed with tissue prior to immunoprecipitation; to do so, two overnight incubations at $4^{\circ} \mathrm{C}$ were employed, using equal volumes of antiserum and pelleted tissue homogenate.

Indirect immunofluorescence. Cultures were grown on coverslips as described above. Cells were fluorescently stained by either of two protocols. By protocol 1, cultures were fixed in 3\% paraformaldehyde in PBS for $15 \mathrm{~min}$. This and all subsequent steps were at room temperature. After three rinses in PBS, the cells were incubated for 15 min in $10 \%$ goat serum (all serum dilutions in PBS) and then with various dilutions of primary antisera for $1 \mathrm{hr}$. After three rinses in PBS, the cultures were incubated for $1 \mathrm{hr}$ with fluorescein-conjugated goat antiguinea pig immunoglobulin (Antibodies, Inc.) at a final dilution of 1:100. The coverslips were then washed in PBS and mounted in buffered glycerol. Cultures were stained with tetanus toxin, by a modification of protocol 1 according to published methods (Mirsky et al., 1978; Hatten and Liem, 1981). Purified tetanus toxin and antisera against tetanus toxin were the generous gifts of Dr. William $\mathrm{H}$. Habig (National Institutes of Health, Bethesda, Md). In protocol 2 (Lee et al., 1977) living cells were incubated with antisera (all serum dilutions in complete medium) for $90 \mathrm{~min}$ at $37^{\circ} \mathrm{C}$. Cells were rinsed in complete medium and a fluorescein- or rhodamine-conjugated secondary antibody was added. After $60 \mathrm{~min}$ at $37^{\circ} \mathrm{C}$, the cells were washed twice in complete medium, and once in PBS. The cultures were then fixed in $3 \%$ paraformaldehyde in PBS, as above, or in absolute methanol $\left(15 \mathrm{~min},-20^{\circ} \mathrm{C}\right)$. In the case of double label experiments, cells were incubated sequentially with anti-NILE GP (1:100) and a rhodamine-conjugated secondary antibody (1:100) according to protocol 2 . Cells were then fixed in methanol and incubated sequentially in rabbit antiglial filament (1:250; anti-GF was a generous gift of Dr. R. K. H. Liem, New York University Medical Center), and fluoresceinconjugated goat anti-rabbit IgG (1:100), according to protocol 1. Coverslips were mounted in either buffered glycerol or polyvinyl alcohol (Feramisco and Blose, 1980). Stretch preparations of rat iris were stained using protocol 2. Whole mounts of guinea pig myenteric plexus were prepared and stained according to the method of Costa et al. (1980). Cells and whole mounts were observed under a Leitz Ortholux microscope equipped with epifluorescent illumination.

SDS-polyacrylamide gel electrophoresis. Electrophoresis was carried out as previously described (Lee et al., 1981) using 7.5 to $15 \%$ gradient polyacrylamide slab gels and the discontinuous SDS-containing buffer system of Laemmli (1970). The sample buffer for electrophoresis consisted of 0.0625 м Tris ( $\mathrm{pH} \mathrm{6.8),5 \%} \mathrm{SDS,} 10 \%(\mathrm{w} / \mathrm{v})$ glycerol, and $1 \%$ mercaptoethanol. Preparative gels, used for purification of NILE-GP, were fixed in $40 \%$ methanol for $10 \mathrm{~min}$, stained with $0.1 \%$ Coomassie brilliant blue in $40 \%$ methanol for $15 \mathrm{~min}$, and destained in distilled $\mathrm{H}_{2} \mathrm{O}$ overnight. Analytical gels were fixed for $1 \mathrm{hr}$ in $40 \%$ methanol/10\% glacial acetic acid, stained for $30 \mathrm{~min}$ in fixative containing $0.1 \%$ Coomassie brilliant blue and destained in 10\% methanol $10 \%$ glacial acetic acid. Molecular weights were estimated on the basis of the following markers: fibronectin, $M_{\mathrm{r}}=230,000$ (generous gift of Dr. D. Rifkin, New York University Medical Center); myosin, $M_{\mathrm{r}}=200,000 ; \beta$-galactosidase, $M_{\mathrm{r}}=116,000 ;$ phosphorylase B, $M_{\mathrm{r}}=96,000$; bovine serum albumin, $M_{\mathrm{r}}$ = 66,000; and ovalbumin, $M_{\mathrm{r}}=45,000$ (all from Biorad). Fluorography was carried out using Enhance (New England Nuclear); Kodak S-R-5 x-ray film was presensitized prior to exposure as described (Laskey and Mills, 1975).

Rocket immunoelectrophoresis. Quantitative immunoelectrophoresis was carried out according to published procedures (Owen and Salton, 1975). Rabbit anti-NILE GP immunoglobulins were purified by ammonium sulfate precipitation and acetate dialysis (Axelsen et al., 1973). PC12 cells $(+/-\mathrm{NGF})$ were labeled with $\left[{ }^{3} \mathrm{H}\right]$ fucose and scraped with a rubber policeman from $100-\mathrm{mm}$ dishes in 
$200 \mu \mathrm{l}$ of buffer A (without SDS and PMSF) as described above. Sample wells were loaded with equal concentrations of protein. Protein concentration was determined by the method of Lowry et al. (1951) using bovine serum albumin as the standard; precipitates caused by Triton $\mathrm{X}-100$ were removed by centrifugation prior to spectrophotometric readings. Following electrophoresis, agarose gels were fluorographed as described above. Rocket areas were measured by tracing the peaks on the fluorogram, cutting them out, and weighing them. The base of the rocket was approximated by a line drawn between the two "feet" of the rocket. The relative induction of NILE GP in PC12 cells treated with NGF was determined by dividing the peak area obtained by rocketing an aliquot of NGF-treated PC12 cell extract by the peak area of an equivalent aliquot of untreated PC12 cell extract.

Cytotoxicity assays. The complement-mediated cytotoxicity of anti-NILE GP against PC12 cells (+/-NGF) and sympathetic neurons was measured as detailed elsewhere (Lee et al., 1980a). Briefly, various dilutions of guinea pig anti-NILE GP and normal guinea pig serum (source of complement) at a final dilution of $1: 4$ were incubated with cell monolayers for $3 \mathrm{hr}$ at $37^{\circ} \mathrm{C}$. Following incubations, PC12 (-NGF) cells were stained with trypan blue, and the percentage of cells killed was determined by microscopy (i.e., those permeable to trypan blue). Cytotoxicity against PC12 (+NGF) cells and sympathetic neurons was scored on a previously described scale (Lee et al., 1980a) as follows: 4, approximately $100 \%$ destruction; 3 , approximately $75 \%$ destruction; 2 , approximately $50 \%$ destruction; 1 , approximately $25 \%$ destruction. Cytotoxic activities against cell bodies and neurites were separately estimated. 'Two types of controls were performed: addition of either antiserum or normal guinea pig serum alone.

\section{Results}

\section{Purification of NILE GP and production of antisera}

NGF was shown to substantially increase the incorporation of radiolabeled fucose into NILE GP (McGuire et al., 1978); on the assumption that this induction actually represented an increase in the level of protein, we chose to purify NILE GP from NGF-treated PC12 cells. Since NILE GP contains carbohydrate, lectin affinity columns were utilized as the first step in the purification scheme. The binding of $\left[{ }^{3} \mathrm{H}\right]$ fucose-labeled $\mathrm{PC} 12$ proteins solubilized with detergent to several lectin-agarose resins was tested and the following fractional recoveries were obtained: WGA (32\%). RCA (29\%), DBA (25\%), Con A $(10 \%)$, and UEA (1\%). NILE GP was found to be selectively retained by RCA-, DBA-, WGA-, and Con A-agarose columns. Identical glycoprotein elution profiles and similar relative recoveries of NILE GP were obtained with the RCA-, DBA-, and WGA-conjugated resins. Con A-agarose retained a qualitatively similar distribution of glycoproteins, but the relative recoveries of NILE GP and several other glycoproteins were reduced. WGA-agarose was initially chosen for preparative work on the basis of its selective retention of NILE GP (Fig. 1) and the high fractional recovery of glycoproteins obtained.
The efficacy of the WGA column to selectively retain glycoproteins was further analyzed by separately running extracts of $\left[{ }^{3} \mathrm{H}\right]$ fucose- and $\left[{ }^{3} \mathrm{H}\right]$ leucine-labeled $\mathrm{PC} 12$ cells. Fluorography of the eluates revealed differences in the electrophoretic patterns, but all showed a prominent 230,000-dalton component that was labeled with either $\left[{ }^{3} \mathrm{H}\right]$ fucose or $\left[{ }^{3} \mathrm{H}\right]$ leucine and stained by Coomassie brilliant blue (Fig. 1, lanes 2, 3, and 5).

NILE GP was purified from PC12 cells grown with NGF $(50 \mathrm{ng} / \mathrm{ml})$ for 10 to 14 days. The cell monolayers from $20(100-\mathrm{mm})$ tissue culture dishes (approximately $10^{7}$ cells/dish) were rinsed wilh PBS and extracted with $1 \%$ sodium deoxycholate in Tris-Cl buffer, $\mathrm{pH}$ 7.8. The extract was centrifuged, and the supernatant was chromatographed on a $10-\mathrm{ml}$ WGA-agarose affinity column (see "Materials and Methods" for details on extraction and affinity chromatography). Bound material was eluted with $0.1 \%$ sodium deoxycholate in Tris- $\mathrm{Cl}$ buffer containing $0.2 \mathrm{~m} N$-acetylglucosamine. The eluate was concentrated to approximately $0.5 \mathrm{ml}$ by pressure dialysis and dialyzed against a buffer containing $0.025 \mathrm{M}$ Tris $(\mathrm{pH}$ 8.3), $0.192 \mathrm{~m}$ glycine, $0.1 \% \mathrm{SDS}$ for $24 \mathrm{hr}$ at $4^{\circ} \mathrm{C}$. The dialysate was combined with sample buffer, boiled, and evenly distributed among six to eight lanes of a 7.5 to 15\% gradient polyacrylamide slab gel. Electrophoresis was terminated $30 \mathrm{~min}$ after the dye front had run off the gel. Gels were then fixed, stained with Coomassie brilliant blue, and destained. The NILE GP band was clearly resolved from the nearest glycoproteins of $M_{\mathrm{r}}=$ 180,000 and approximately 300,000 (Fig. 1, indicated by the lower and upper arrows to the left of lane 5, respectively) and could be excised from preparative gels using plasma fibronectin as a marker. The NILE GP purified in this manner was then used to raise several antisera (see "Materials and Methods").

\section{Antibody specificity}

The activity of antisera raised against purified NILE GP (anti-NILE GP) was initially tested by immunoprecipitation analysis of radiolabeled PC12 cell proteins and examination, by indirect immunofluorescence, of PC12 cell staining. By these criteria, the four guinea pigs and two rabbits that were immunized with purified NILE GP each produced an antiserum directed against NILE GP.

To test the specificity of the antisera, NGF-treated and -untreated PC12 cells were metabolically labeled with $\left[{ }^{3} \mathrm{H}\right]$ fucose or $\left[{ }^{3} \mathrm{H}\right]$ glucosamine and were solubilized in buffer A (see "Materials and Methods"). Antisera against NILE GP (10- to 200-fold dilution) was found to selectively immunoprecipitate a single 230,000-dalton glycoprotein from these extracts (Fig. 1, lane 6). Preimmune or normal sera did not precipitate detectable $\left[{ }^{3} \mathrm{H}\right]$ fucose-labeled bands (Fig. 1, lane 7), nor did antisera pre-absorbed with $\mathrm{PC} 12$ cells. Material immunoprecipitated from NGF-treated and -untreated cells had identical mobilities on SDS-polyacrylamide gels (see Fig. 11, lanes 10 and 11), and co-migrated with NILE GP in detergent extracts of PC12 cells. In immunoprecipitation experiments employing 2 - to 5 -fold dilutions of anti-NILE GP, a 230,000-dalton band was visualized after staining with Coomassie brilliant blue. Furthermore, the NILE 
GP antisera selectively precipitated a single 230,000 -dalton band from extracts of $\left.{ }^{35} \mathrm{~S}\right]$ methionine-labeled PC12 cells (Fig. 1, lane 8).

\section{Cell surface localization of anti-NILE GP on PC12 cells}

Indirect immunofluorescence was employed to characterize the antisera and to localize NILE GP. Anti-NILE GP (up to a 500 -fold dilution) stained the surfaces of living NGF-treated and -untreated PC12 cells (Fig. 2). The apparent capped staining distribution and variation in the staining intensity seen in Figure 2 are in part a function of the plane of focus; focusing up and down revealed a patchy, spotty staining pattern that was widely distributed over the cell surface. However, paraformaldehyde fixation of cultures prior to immunofluorescent staining, or staining of live cells at $4^{\circ} \mathrm{C}$, led to a relatively less patchy staining distribution, suggesting that some redistribution of NILE GP occurred during the staining of live PC cells at $37^{\circ} \mathrm{C}$. Staining of NGF-treated PC12 cells was distributed over the surfaces of cell bodies and neurites (Fig. 2, $b$ and $c$ ); comparison of phase and fluorescent images revealed that all PC12 cell bodies and processes were stained. Staining of growth cones was also consistently noted (Fig. 2, $c$ and $f$ ), but substrate staining was not detected. Pre-immune sera did not show significant levels of staining.

One property of NILE GP and an indication of its cell surface localization is its sensitivity to mild trypsinization (McGuire et al., 1978; Lee et al., 1981). In the current studies, the 230,000-dalton glycoprotein which is recognized by anti-NILE GP was similarly affected by trypsin. Limited incubation of intact $\left[{ }^{3} \mathrm{H}\right]$ fucose-labeled PC12 cells with either trypsin (see "Materials and Methods;" Fig. 3) or pronase converted the 230,000-dalton glycoprotein recognized by anti-NILE GP at least in part into a fucosylated 90,000-dalton membrane-bound immuno-

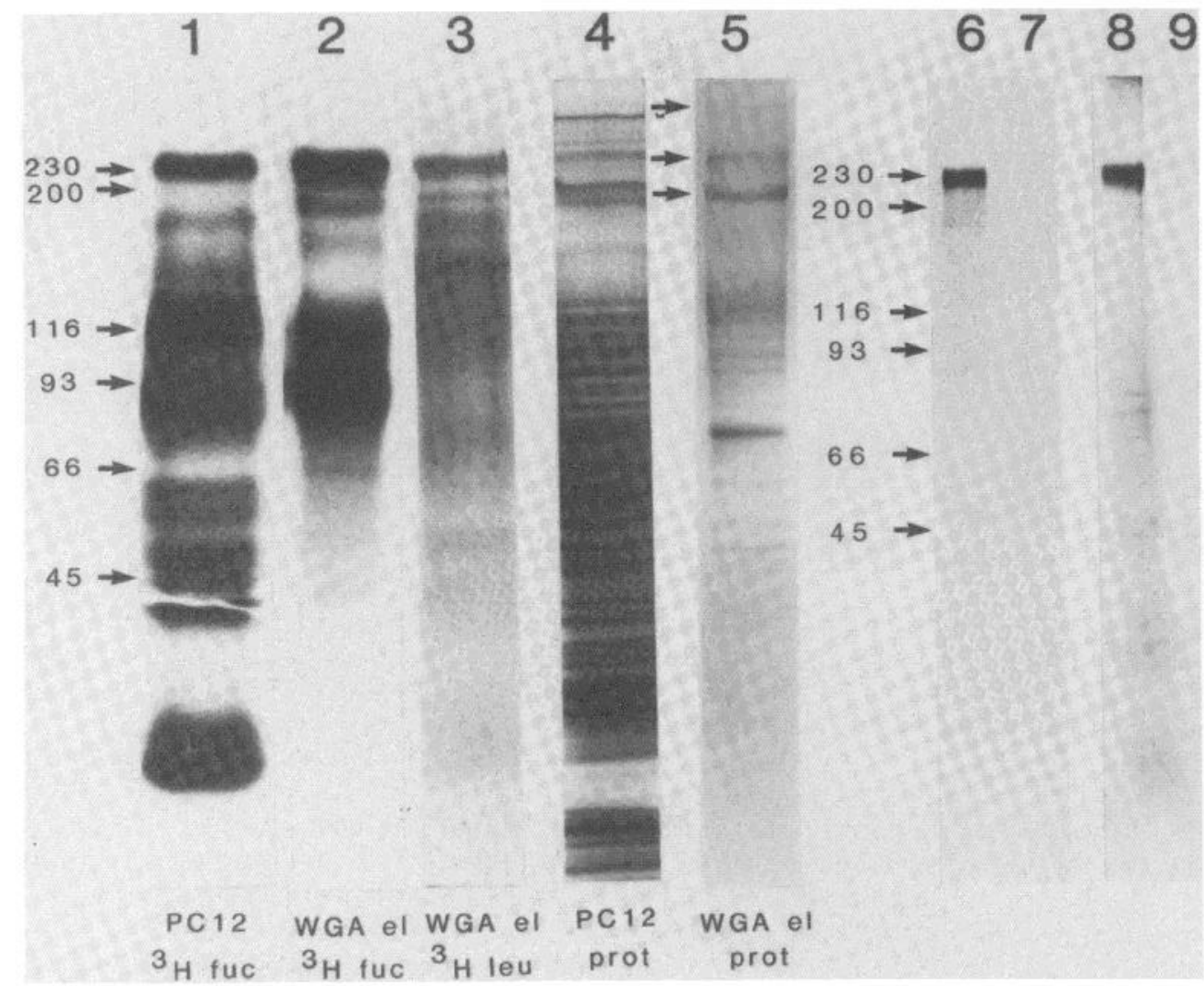

Figure 1. Lanes 1 to 5 , SDS-PAGE analysis of WGA column eluates. NGF-treated PC12 cells were labeled with either [ $\left.{ }^{3} \mathrm{H}\right]$ fucose or $\left[{ }^{3} \mathrm{H}\right]$ leucine, extracted with sodium deoxycholate, and the extract was chromatographed on WGA-agarose affinity columns. Lane 1 shows a fluorograph of the $\left[{ }^{3} \mathrm{H}\right]$ fucose-labeled glycoproteins in the extract prior to chromatography; Lane 4 shows the Coomassie blue-stained pattern of proteins in lane 1 and, therefore, represents total cell proteins. Lane 2 shows a fluorograph of the $\left[{ }^{3} \mathrm{H}\right]$ fucose-labeled glycoproteins in the WGA eluate; lane 5 shows the same profile stained with Coomassie blue. Lane 3 shows a fluorograph of $\left[{ }^{3} \mathrm{H}\right]$ leucine-labeled proteins in the WGA column eluate. Positions of molecular weight markers are indicated by the labeled arrows. The positions of NILE GP and the nearest glycoproteins of 300,000 and 180,000 daltons are indicated by the arrows to the left of lane 5. Lanes 6 to 9, indirect immunoprecipitation of radiolabeled PC12 cells with anti-NILE GP. NGF-treated PC12 cells were labeled with either $\left[{ }^{3} \mathrm{H}\right]$ fucose or $\left[{ }^{35} \mathrm{~S}\right]$ methionine and were extracted with buffer A, and immunoprecipitation analysis was carried out as described under "Materials and Methods." Immunoprecipitates were analyzed by SDS-PAGE and fluorography. Aliquots of 50,000 TCA-precipitable [ $\left.{ }^{3} \mathrm{H}\right]$ fucose cpm or 500,000 TCA-precipitable $\left[{ }^{35} \mathrm{~S}\right]$ methionine cpm were immunoprecipitated with either anti-NILE GP (lanes 6 and 8 , respectively) or pre-immune serum (lanes 7 and 9, respectively). Positions of molecular weight markers are indicated by arrows. 

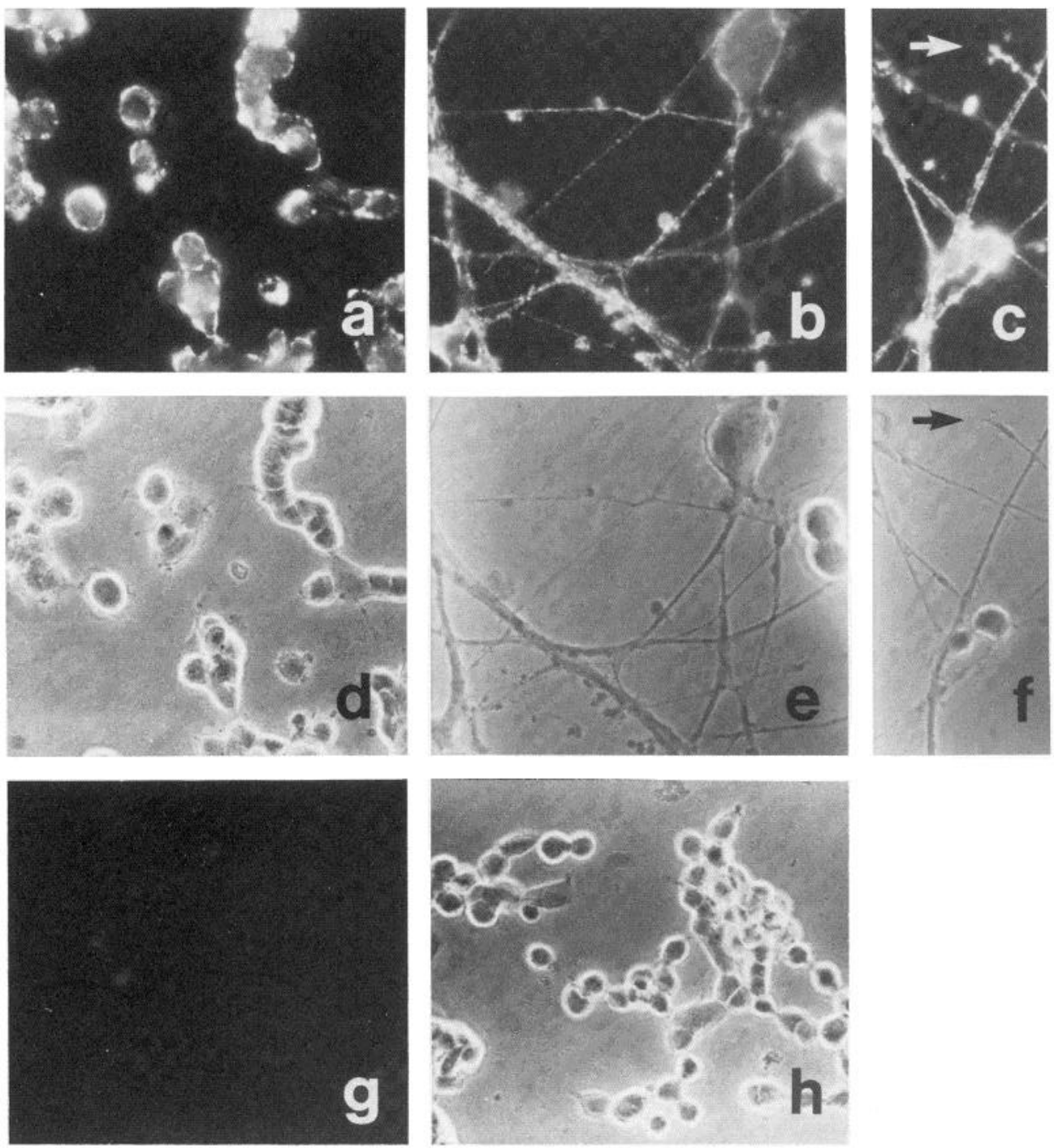

Figure 2. Indirect immunofluorescence of PC12 cells. Live PC12 cells were immunofluorescently stained using 1:100 dilutions of antisera according to protocol 2 under "Materials and Methods." Untreated $(a, \times 300)$ and NGF-treated $(b$ and $c, \times 515)$ PC12 cells, stained with anti-NILE GP (1:100) and the corresponding phase pictures, $d, e$, and $f$, respectively, are shown. Staining of a growth cone is indicated by the arrow in $c$ and $f$. Staining of untreated PC12 cells with pre-immune serum is shown in $g$, and the corresponding field under phase illumination is shown in $h(\times 325)$.

reactive fragment. The presence of immunoreactive fragments on the cell surface following trypsinization was further suggested by the observation that trypsinized PC12 cells retained the capacity to be immunofluorescently stained by anti-NILE GP.

Complement-mediated cytotoxicity assays also suggested that the antisera recognized the cell surface. In the presence of complement, anti-NILE GP was cytotoxic to both untreated and NGF-treated PC12 cells (Fig. 4, $A$ and $B$ ). To achieve comparable destruction of NGFtreated and -untreated cells, approximately 5 -fold higher concentrations of antiserum seemed to be needed in the case of NGF-treated cells. Interpretation of these differences is difficult since it was necessary to use different scoring systems for NGF-treated and -untreated PC12 cells. Destruction of the cell bodies of NGF-treated PC12 cells required 2-fold higher concentrations of anti-NILE GP than was necessary to destroy neurites (Fig. $4 B$ ), suggesting that NILE GP is present on the surfaces of both cell bodies and processes and that neurites are susceptible to the cytotoxic action of anti-NILE GP in the absence of cell body destruction. Cytotoxicity against cultured sympathetic neuron cell bodies and neurites was also obtained (Fig. $4 \mathrm{C}$ ) and at concentrations similar to those required to destroy NGF-treated PC12 cells.

\section{Induction of NILE GP by NGF}

It has been demonstrated that treatment of $\mathrm{PC} 12$ cells with NGF increases the incorporation of radiolabeled fucose or glucosamine into NILE GP and that this increase occurs gradually over a time course of days (McGuire et al., 1978). In the present studies quantitative rocket immunoelectrophoresis suggested that the action of NGF on NILE GP represents an actual increase in the amount of protein, rather than a selective change in carbohydrate incorporation. Using this method, a 3- to 
5 -fold increase in the specific level of NILE GP relative to total cell protein was detected in PC12 cells treated for 2 weeks with NGF (Fig. 5). Several studies quantifying the induction of NILE GP in NGF-treated PC12 cells are presented in graphic form in Figure 6. The most pronounced increase in the amount of NILE GP occurred during the second to fifth days of exposure to NGF. The level of NILE GP progressively increased with further exposure to NGF; NILE GP was generally more promi-

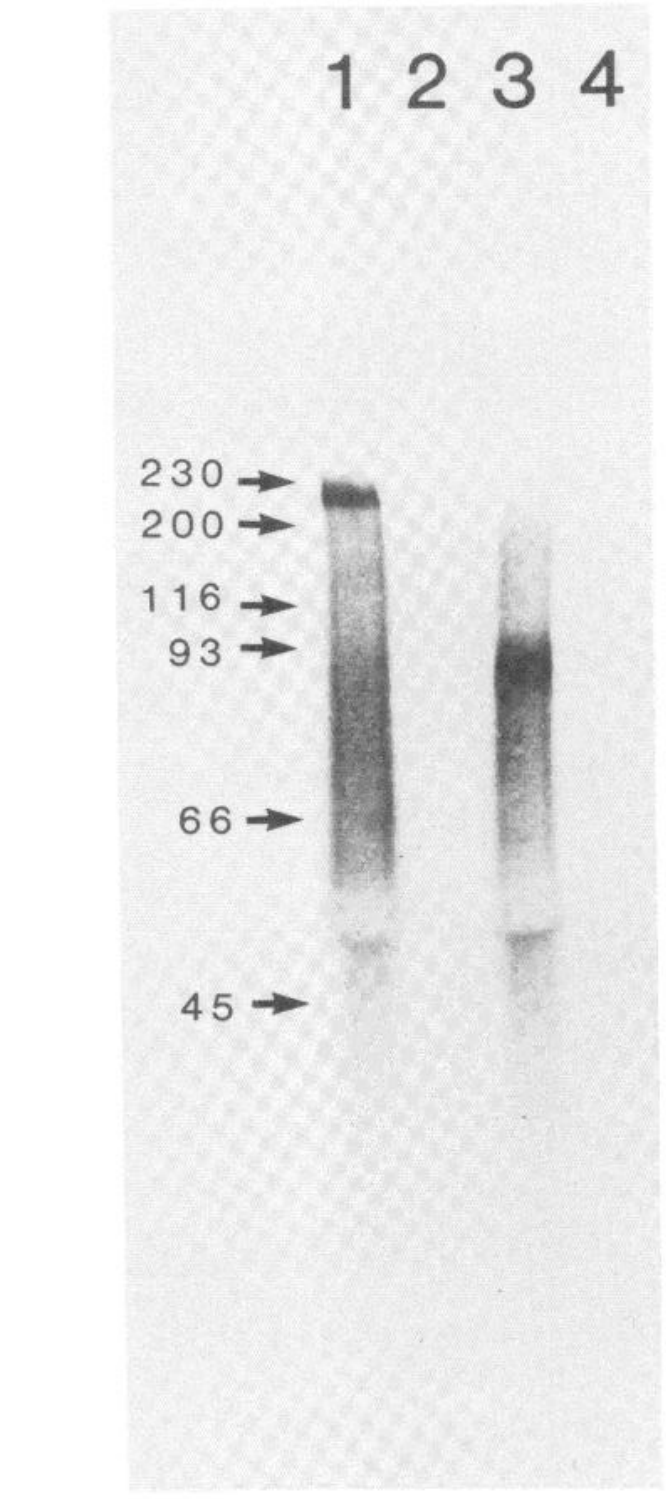

Figure 3. Immunoprecipitation of trypsinized and untreated PC12 cell membranes. Intact, $\left[{ }^{3} \mathrm{H}\right]$ fucose-labeled PC12 cells grown in the absence of NGF were incubated with and without trypsin. Crude membranes were then isolated and extracted in buffer A. Aliquots were immunoprecipitated and analyzed by SDS-PAGE and fluorography. Bands selectively immunoprecipitated by anti-NILE GP from untrypsinized PC12 cells and from trypsinized $\mathrm{PC} 12$ cells are shown in lanes 1 and 3, respectively. Material immunoprecipitated by pre-immune serum from untrypsinized and trypsinized PC12 cells is shown in lanes 2 and 4, respectively. Similar results were obtained with NGFtreated PC12 cells. Positions of molecular weight markers are indicated by arrows. nent after 21 days of treatment with NGF than after 14 days of treatment.

\section{Distribution of NILE GP}

The tissue and cellular distribution of NILE GP was assayed by three independent criteria: (1) tissue absorption of anti-NILE GP; (2) immunofluorescent staining of primary cell cultures and whole mount tissue preparations; and (3) immunoprecipitation of detergent-extracted primary cell cultures metabolically labeled with $\left[{ }^{3} \mathrm{H}\right]$ fucose. These findings are summarized in Table I.

Absorption. Anti-NILE GP was absorbed with adult rat tissues and then was used to immunoprecipitate NILE GP from $\left[{ }^{3} \mathrm{H}\right]$ fucose-labeled PC12 cell extracts. Absorption with brain tissue completely removed immunoreactivity toward NILE GP, whereas repeated absorption with liver, spleen, skeletal muscle, or cardiac muscle did not. Previous absorption studies have also indicated that NILE GP is absent from kidney and thymus (Lee et al, 1981). Within brain, homogenates of cerebellum, cerebral cortex, and midbrain were each capable of completely removing anti-NILE GP immunoreactivity.

Cellular distribution of NILE GP. Immunohistofluorescence experiments were designed to determine the tissue and cellullar distribution of NILE GP. Expression of NILE GP was examined by indirect immunofluorescence in the following primary neural cell culture systems: cerebellum, cerebral cortex, spinal cord, dorsal root ganglia, and superior cervical ganglia. All cells in peripheral nervous system (PNS) cultures, and many if not all cells in central nervous system (CNS) cultures, identified morphologically as neurons (i.e., possessing extended, fine caliber processes and raised cell bodies) were stained with anti-NILE GP (Figs. 7 and 8). The widespread, spotty distribution of NILE GP on cell bodies and neurites closely resembled that found on the cell surfaces of NGF-treated PC12 cells (compare Figs. 8 and 2). Unambiguous identification of cultured neuronal and nonneuronal cells in CNS cultures based solely on morphological criteria was not always possible, precluding an absolute correlation of anti-NILE GP staining with "neuronal" phenotype in such cases.

To confirm that staining in CNS cultures was exclusive to neurons, cells dissociated from rat cerebellum were identified using cell type-specific probes. Tetanus toxin is known to bind specifically to the surfaces of cultured neurons (Mirsky et al., 1978). When the immunofluorescent staining patterns of anti-NILE GP and tetanus toxin were compared on paraformaldehyde-fixed cultured cerebellar cells, very similar distributions were observed (Fig. 7, $d$ and $e$ ). In addition, staining of live cerebellar cultures with anti-NILE GP, followed by fixation in methanol and staining with anti-GF (antiglial filament protein), an astroglial marker, in double label immunofluorescence studies indicated that NILE GP was not expressed by cerebellar astrocytes. The cells and processes stained by anti-NILE GP were clearly distinct from those stained by anti-GF (Fig. 7, $a$ to $c$ ). Presumptive neuronal processes were occasionally observed to run along the surfaces of glial processes. Consistent with the absence of NILE GP staining on cultured cerebellar 

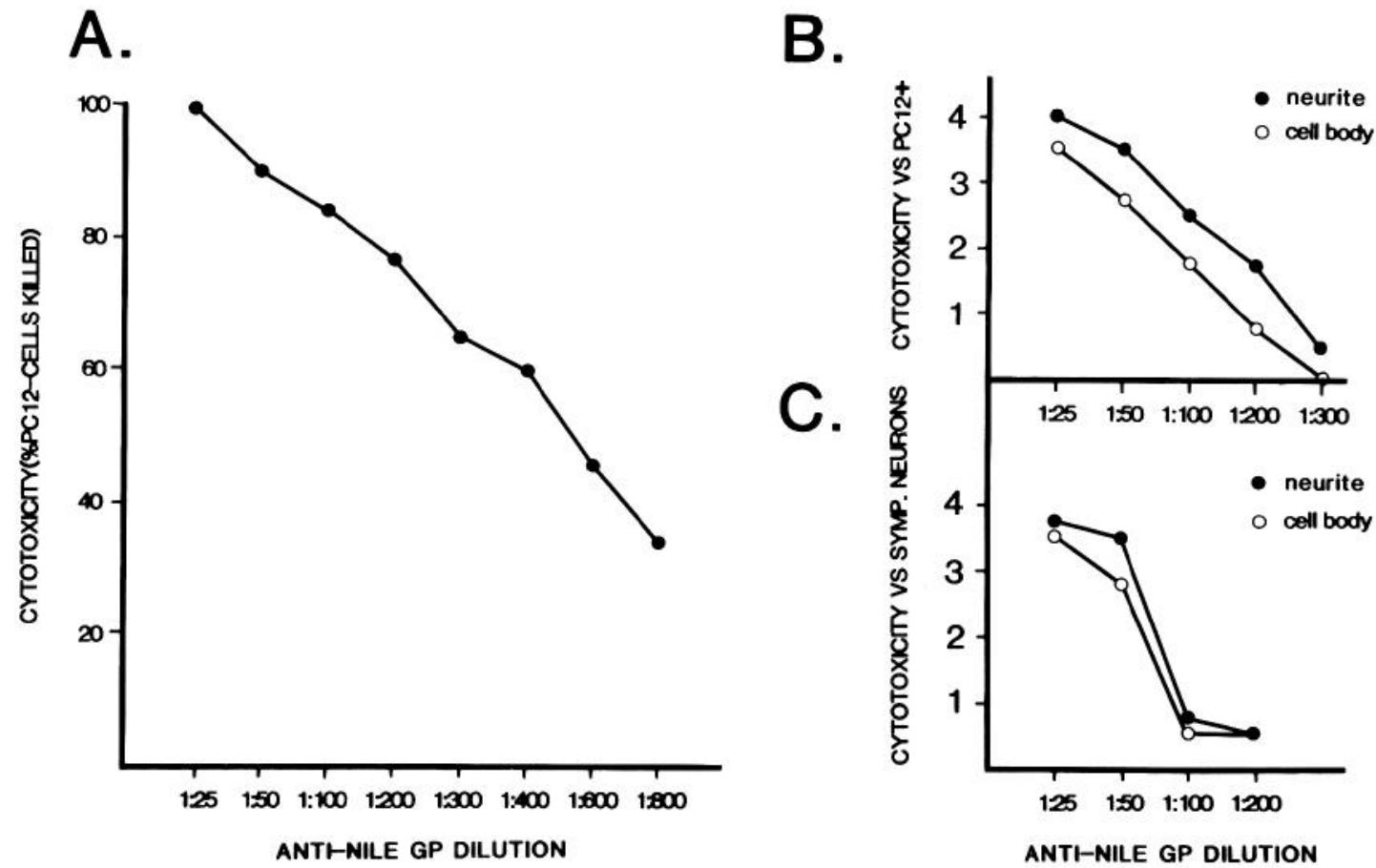

Figure 4. Complement-mediated cytotoxicity assays. Individual cultures of PC12 cells, treated with $(B)$ and without NGF $(A)$, and sympathetic neurons $(C)$ were incubated in various dilutions of guinea pig anti-NILE GP $(x$ axis) in the presence of complement. Cytotoxicity of untreated PC12 cells was quantified by determining the percentage of cells killed; data points are an average of three fields, each containing at least 200 cells $(A, y$ axis). Destruction of the cell bodies and processes of NGF-treated $\mathrm{PC} 12$ cells $(B, y$ axis $)$ and sympathetic neurons $(C, y$ axis $)$ was quantified on a graduated scale as described under "Materials and Methods." For these assays, the dishes $(35 \mathrm{~mm})$ contained approximately 1 to $3 \times 10^{5}$ sympathetic neurons and $2 \times 10^{5}$ NGFtreated PC12 cells, respectively.

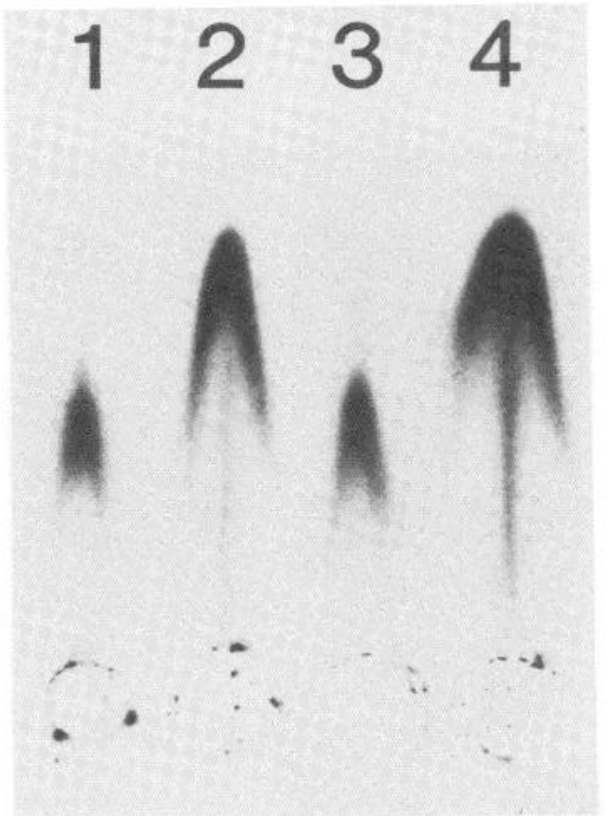

Figure 5. Induction of NILE GP in PC12 cells treated with NGF. PC12 cell cultures, either untreated or treated with NGF for 14 days, were labeled with $\left[{ }^{3} \mathrm{H}\right]$ fucose and extracted in buffer A (without SDS and PMSF). The level of NILE GP was quantified by rocket immunoelectrophoresis. Samples were loaded as follows: $70 \mu \mathrm{g}$ of total protein from NGF-treated (lane 1) and -untreated (lane 2) cell extracts and $43 \mu \mathrm{g}$ of total astroglia was the observation that the C6 glioma cell line neither synthesized nor expressed cell surface NILE GP.

Additional experiments were performed to characterize the distribution of NILE GP in the PNS. Cultured SCG contain three predominant cell types: sympathetic neurons, Schwann cells, and capsular fibroblasts (Chamley et al., 1972). Immunofluorescence studies of rat SCG cultures (postnatal day 2, 2 to 8 days in vitro) revealed that all processes and cell bodies of sympathetic neurons were stained with anti-NILE GP (Fig. $8 c$; all cell bodies were stained but some are not in the plane of focus), whereas the surfaces of capsular fibroblasts (Fig. 9) were not. The close association between peripheral Schwann cells and sympathetic neurons in SCG cultures complicated the assessment of Schwann cell staining. Sympathetic neurons, however, could be eliminated from SCG cultures by removing NGF, a trophic substance required for their survival in vitro (Levi Montalcini and Angeletti, 1963). SCG were dissociated and maintained without exogenous NGF and in the presence of anti-NGF antiserum. Under these conditions, cultured sympathetic neurons degenerated within $72 \mathrm{hr}$ of the initial dissocia-

protein from NGF-treated (lane 3) and -untreated (lane 4) cell extracts. With antibody concentration fixed, rocket area is proportional to the amount of antigen present (Axelsen et al., 1973). The relative induction of NILE GP, determined from a ratio of the peak areas, ranged from 3.1 (peak 3/peak 4) to 4.1 (peak 1/peak 2). 


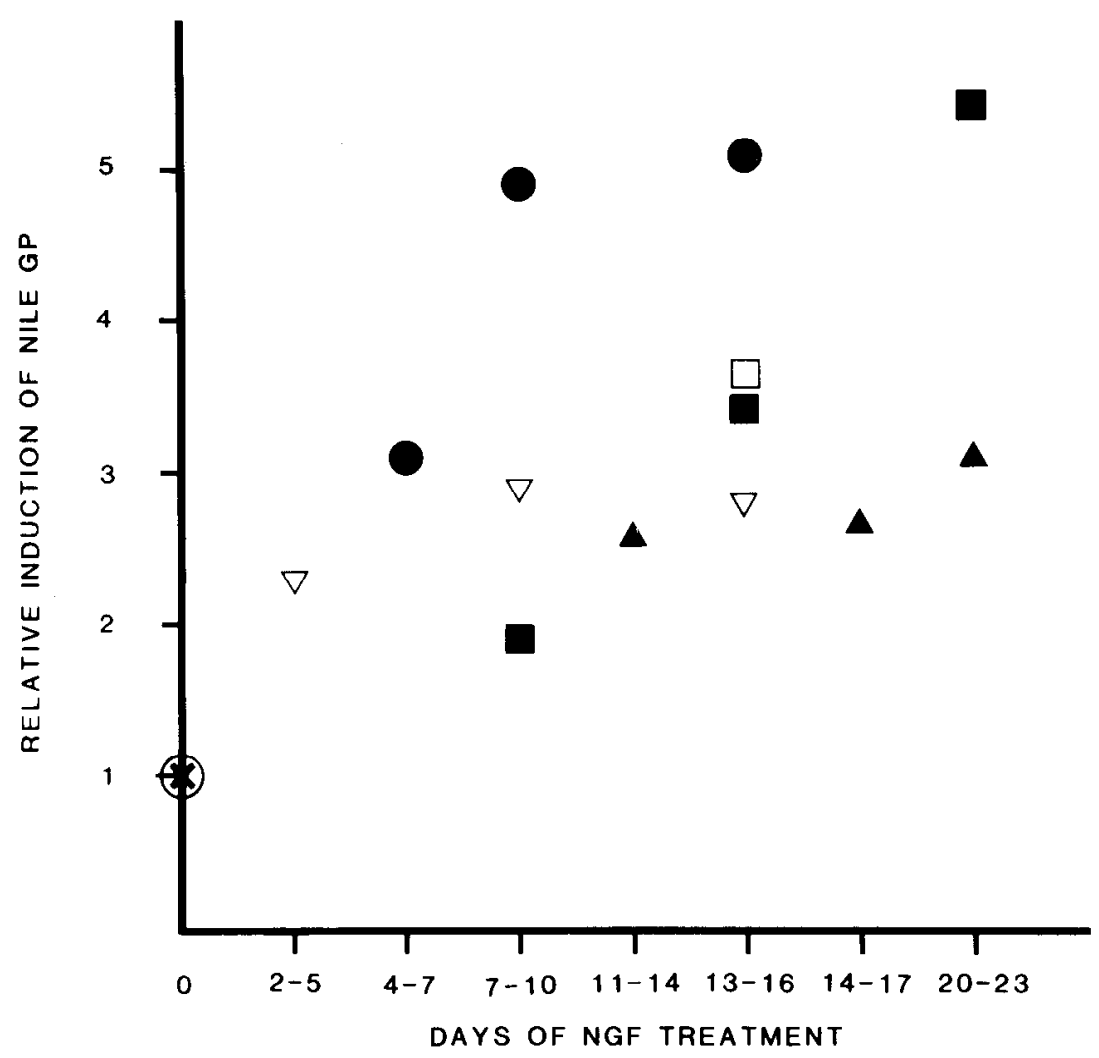

Figure 6. Time course of NILE GP induction quantified by rocket immunoelectrophoresis. PC12 cell cultures were grown in the absence or in the presence of NGF. After varying periods of NGF treatment, growth medium was supplemented with 10 to 20 $\mu \mathrm{Ci} / \mathrm{ml}$ of $\left[{ }^{3} \mathrm{H}\right]$ fucose, and the cells were labeled for $72 \mathrm{hr}$. Sister cultures were then extracted, and the amount of NILE GP present was quantified, on the same gel, by rocket immunoelectrophoresis (see Fig. 5 and "Materials and Methods"). Each symbol represents a different experimental series of sister cultures.

tion. Expression of NILE GP was examined in these NGF-deprived cultures, comprised of Schwann cells and fibroblasts, after 6 days in vitro. As in NGF-treated cultures, anti-NILE GP did not stain isolated fibroblasts in NGF-deprived cultures (Fig. 9). Schwann cell surfaces were stained in a very faint, irregular, and diffuse pattern which, however, was absent in control cultures stained with pre-immune serum (Fig. 9). No intensely stained cells (e.g., surviving sympathetic neurons or NGF-insensitive neurons) were detected. Immunoprecipitation analysis of NGF-deprived SCG cultures, labeled with $\left[{ }^{3} \mathrm{H}\right]$ fucose, revealed that a small, but readily detectable, amount of NILE-cross-reactive material was synthesized. This material migrated on SDS-polyacrylamide gels with a mobility similar to that of the NILE GP synthesized by PC12 cells (Fig. 9). This result, in conjunction with the immunofluorescence studies, suggests that Schwann cells synthesize and express on their surfaces a low level of a NILE GP-cross-reactive material.

Expression of NILE GP by a number of additional cell types was investigated. By indirect immunofluorescence, spontaneously contracting primary cultures of skeletal and cardiac muscle, as well as a transformed gerbil fibroma cell line (CCL-146), did not express cell surface NILE GP. In contrast, murine N115 neuroblastoma cells, and NGF-treated and -untreated human NB5 neuroblastoma cells were found to synthesize and express NILE GP.
TABLE I

Cell and tissue distribution of NILE GP

Presence $(+)$ or absence $(-)$ of immunoreactive NILE GP was assayed by tissue absorption of anti-NILE GP (Abs), indirect immunofluorescence (IF), and immunoprecipitation (IP).

\begin{tabular}{|c|c|c|}
\hline Cell or Tissue & NILE GP & Criteria \\
\hline $\begin{array}{l}\text { PC12 pheochromocytoma } \\
\text { (+/-NGF) }\end{array}$ & + & IP, IF, Abs \\
\hline $\begin{array}{l}\text { Human NB5 neuroblastonia } \\
(+/-\mathrm{NGF})\end{array}$ & + & IP, IF \\
\hline Murine N115 neuroblastoma & + & IP, IF \\
\hline Gerbil fibroma & - & IF \\
\hline C6 glioma & - & $\mathrm{IP}, \mathrm{IF}$ \\
\hline Sensory neurons & + & IP, IF \\
\hline Sympathetic neurons & + & IP, IF \\
\hline Schwann cells & + & IP, IF \\
\hline Capsular fibroblasts & - & IF \\
\hline Cerebral cortex & + & $\mathrm{IP}, \mathrm{IF}, \mathrm{Abs}$ \\
\hline Cerebellum & + & $\mathrm{IP}, \mathrm{IF}, \mathrm{Abs}$ \\
\hline Spinal cord & + & IP, IF \\
\hline Skeletal muscle & - & $\mathrm{IP}, \mathrm{IF}, \mathrm{Abs}$ \\
\hline Cardiac muscle & - & IF, Abs \\
\hline Iris (autonomic neurons) & + & IF \\
\hline Ileum (myenteric plexus) & + & IF \\
\hline Liver & - & Abs \\
\hline Spleen & - & Abs \\
\hline Kidney & - & $\operatorname{Abs}^{a}$ \\
\hline Thymus & - & $\mathrm{Abs}^{\prime \prime}$ \\
\hline
\end{tabular}

${ }^{a}$ Data from Lee et al. (1981). 

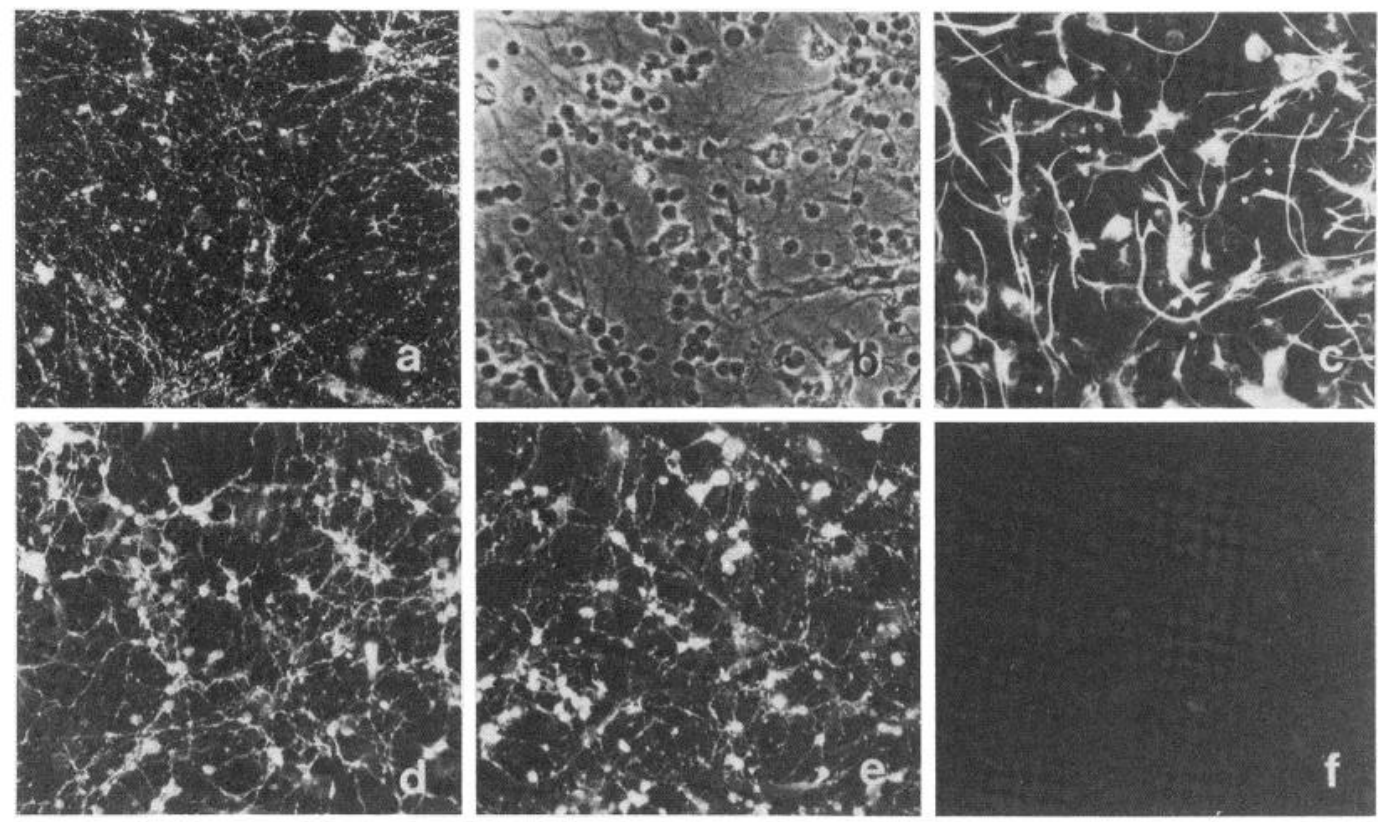

Figure 7. Indirect immunofluorescence of cultured cerebellum. In $a$ to $c$, living cerebellar cells (P5, 6 days in culture) were immunofluorescently stained with guinea pig anti-NILE GP (1:100) and rhodamine-goat anti-guinea pig IgG (GAGP; 1:100), then fixed and stained with rabbit anti-GF (1:250) and fluorescein-goat anti-rabbit IgG (1:100). The same field $(\times 150)$ is shown under rhodamine excitation $(a)$, fluorescein excitation $(c)$, and phase illumination $(b)$. In $d$ to $f,(\times 150)$, cerebellar cultures were fixed and stained according to protocol 1 . In $e$, cells were incubated sequentially in tetanus toxin $(0.5 \mu \mathrm{g} / \mathrm{ml})$, goat antitetanus toxin $(1: 50)$, and fluorescein-rabbit anti-goat IgG (1:100). Sister cultures were stained with either anti-NILE GP $(d, 1: 100)$ or preimmune serum $(f, 1: 100)$ and fluorescein-GAGP.
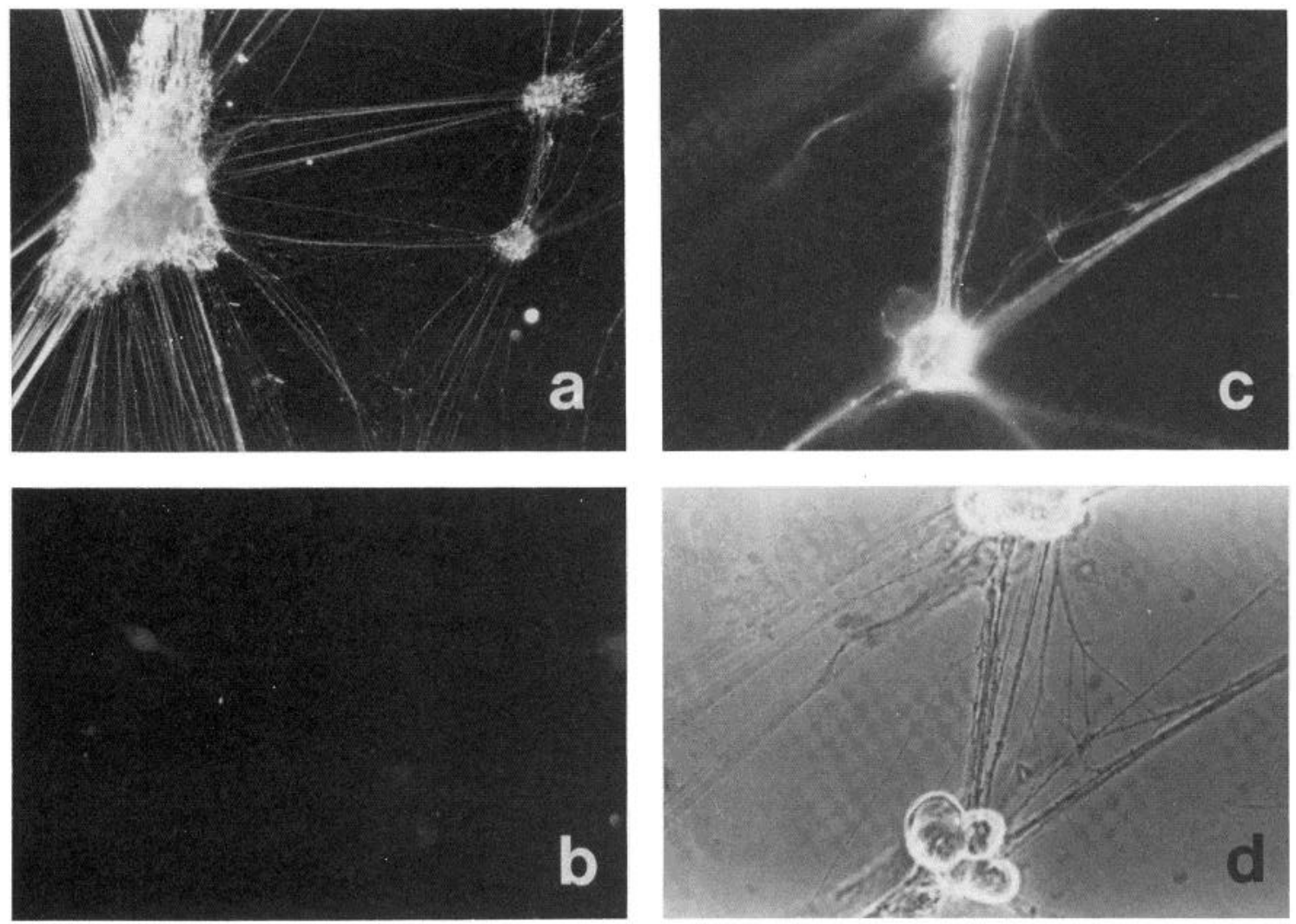

Figure 8. Indirect immunofluorescence of cultured sympathetic neurons with anti-NILE GP. Superior cervical ganglia cultures were immunofluorescently stained with anti-NILE GP (1:100) according to protocol 2 . Staining of sympathetic neurons is shown in panel $(\mathrm{a})(\times 1)$, and at a greater magnification $(\times 300)$ in $c$ with the corresponding field under phase illumination shown in $d$. Staining of SCG cultures with pre-immune serum $(1: 100)$ is shown in $b(\times 110)$. 


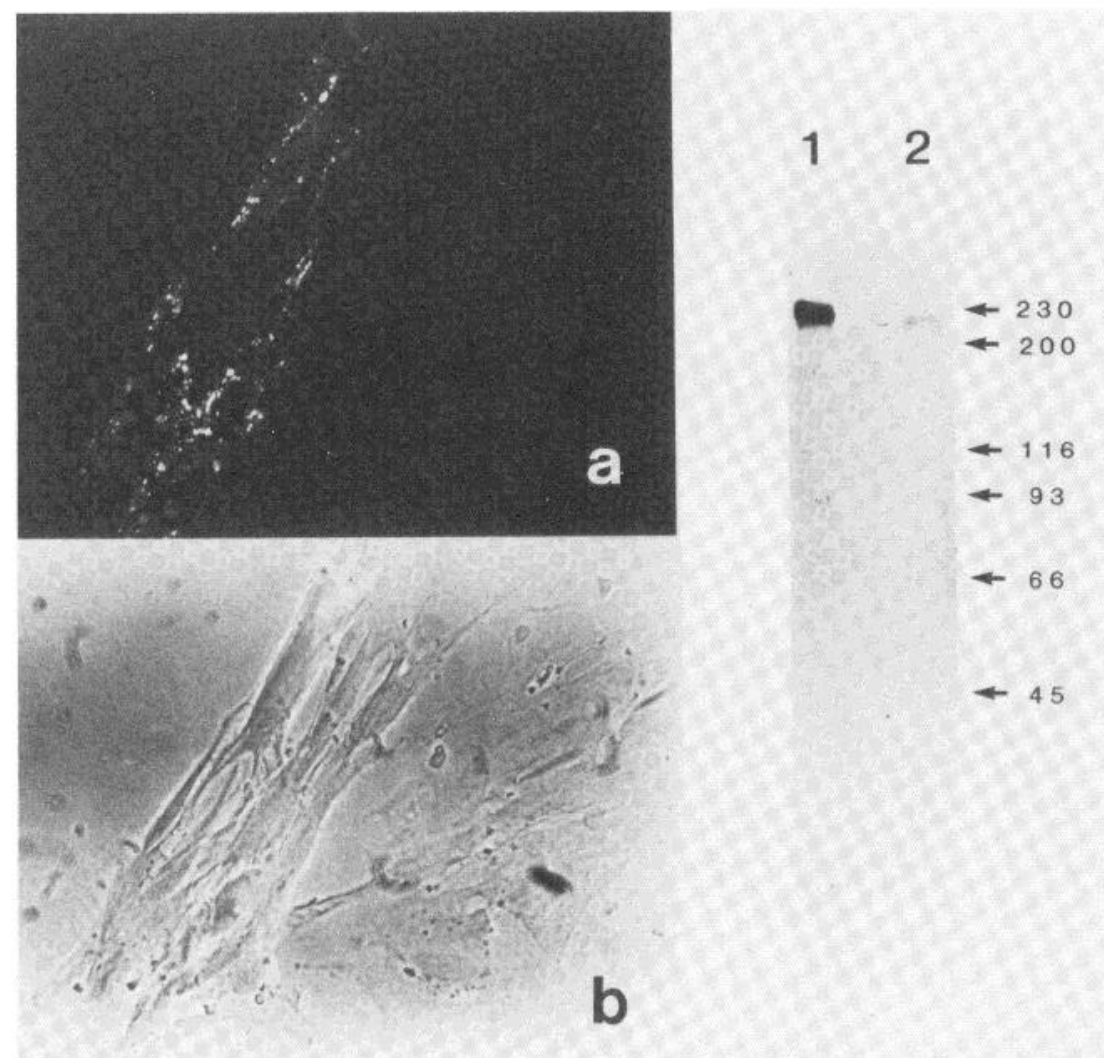

Figure 9. Indirect immunofluorescence and immunoprecipitation of NGF-deprived SCG cultures with anti-NILE GP. NGFdeprived SCG cultures were immunofluorescently stained with anti-NILE GP (1:100) according to protocol 2 . Schwann cells are stained but fibroblasts are not $(a)$. The corresponding field under phase illumination is shown in $b(\times 275)$. NGF-deprived SCG cultures were also labeled with $\left[{ }^{3} \mathrm{H}\right]$ fucose for $72 \mathrm{hr}$ and extracted in buffer $\mathrm{A}$, and an aliquot was immunoprecipitated with antiNILE GP and analyzed by SDS-PAGE (lane 2). An aliquot of fucose-labeled PC12 (+NGF) cell extract, containing an equal number of TCA-precipitable cpm, was immunoprecipitated and electrophoresed in lane 1. Mobilities of molecular weight standards are indicated on the right.
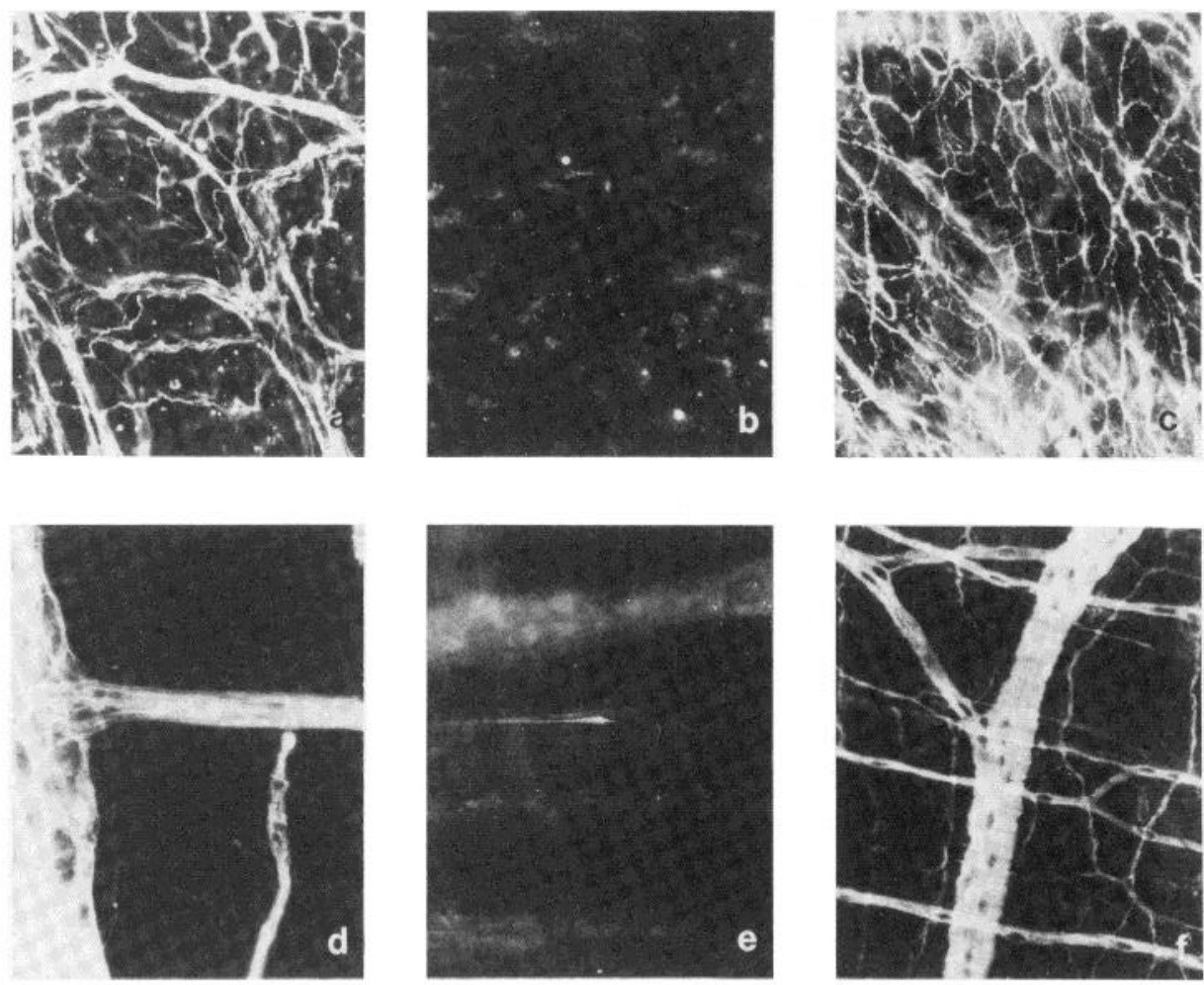

Figure 10. Immunofluorescent staining of tissue whole mounts with anti-NILE GP. Tissue whole mount preparations were stained by indirect immunofluorescence as described in under "Materials and Methods." Anti-NILE GP (1:100) stained fiber bundles and fine processes in rat iris ( $a$ and $c$, respectively). Staining of iris with pre-immune serum (1:100) is shown in $b$ (all $\times$ 100). Anti-NILE GP (1:100) staining of guinea pig myenteric and tertiary plexuses is shown in $d$ and $f$, while pre-immune serum $(1: 100)$ staining is shown in $e($ all $\times 120)$. 


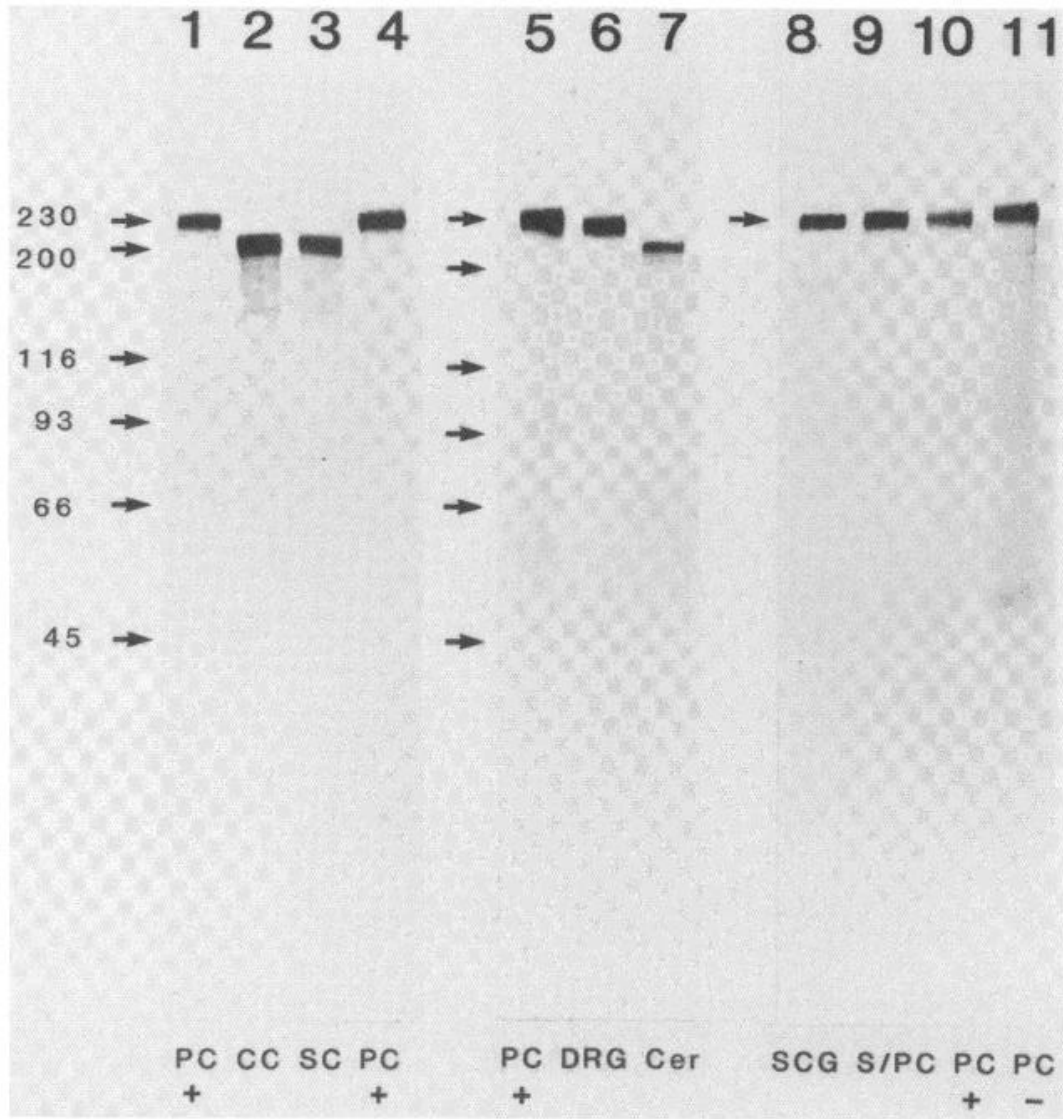

Figure 11. Indirect immunoprecipitation of primary neuronal cultures and PC12 cells with anti-NILE GP. PC12 cells and primary cultures were labeled with $\left[{ }^{3} \mathrm{H}\right]$ fucose, solubilized in buffer $\mathrm{A}$, and immunoprecipitated. Immunoprecipitates were analyzed by SDS-PAGE and fluorography. To generate lanes 1 to 7, the following samples containing 30,000 to 50,000 TCAprecipitable $\left[{ }^{3} \mathrm{H}\right]$ fucose cpm were immunoprecipitated using guinea pig anti-NILE GP: NGF-treated PC12 cells $(P C+$, lanes 1,4 , and 5), and cultured cerebral cortex (CC, lane 2), spinal cord (SC, lane 3), DRG (lane 6), and cerebellum (Cer, lane 7). To generate lanes 8 to 11 , rabbit anti-NILE GP was used to immunoprecipitate aliquots containing 20,000 TCA-precipitable [ $\left.{ }^{3} \mathrm{H}\right]$ fucose cpm of cultured SCG (lane 8), NGF-treated PC12 cells (PC+, lane 10), and untreated PC12 cells (PC-, lane 11). A mixture of the components electrophoresed in lanes 8 and 10 was run in lane $9(S / P C)$. Positions of molecular weight markers are indicated by the arrows.

The in situ localization of NILE GP in the PNS was evaluated by tissue whole mount immunofluorescent staining. Anti-NILE GP staining of rat iris (Fig. 10), a tissue rich in autonomic innervation, was very similar in distribution to the formaldehyde-induced catecholamine fluorescence exhibited by sympathetic neurons. The longitudinal muscle layer and adhering myenteric plexus of the guinea pig ileum were also examined. Neuronal fibers associated with the myenteric and tertiary plexuses were stained with anti-NILE GP (Fig. 10). Because of this intense staining, it was not possible to determine with certainty whether the cell bodies within the myenteric plexus express NILE GP. Longitudinal smooth muscle was clearly not recognized by anti-NILE GP (Fig. 10). Attempts to immunohistochemically stain fixed and frozen sections of PNS and CNS tissues with anti-NILE GP, using either fluorescence or the peroxidase-antiperoxidase procedure (Sternberger, 1979), were unsuccessful.

Synthesis of NILE-cross-reactive GPs. To assess the molecular properties of their NILE-cross-reactive glycoproteins, primary cell cultures of rat cerebellum, cerebral cortex, spinal cord, SCG, and DRG were pretreated with cytosine arabinoside to eliminate dividing non-neuronal cells, labeled with $\left[{ }^{3} \mathrm{H}\right]$ fucose, and extracted in buffer $\mathrm{A}$ (see "Materials and Methods"). Subsequent immunoprecipitation experiments revealed synthesis of NILE-crossreactive glycoproteins in each of the above culture systems. Cultures dissociated from the PNS (SCG and DRG) synthesized a glycoprotein which was selectively immunoprecipitated by anti-NILE GP and migrated on SDS-polyacrylamide gels at a position similar to the NILE GP synthesized by PC12 cells (Fig. 1i, lanes 6 and 8 ). Cells dissociated from CNS tissues synthesized an apparently smaller 200,000 - to 210,000 -dalton glycoprotein which was also selectively recognized by anti-NILE GP (Fig. 11, lanes 2, 3, and 7). This difference in molecular weight does not appear to reflect a difference in proteolytic activity associated with CNS cultures because combination of unlabeled cerebellar cultures and labeled PC12 cells prior to extraction did not alter the molecular weight of labeled, immunoprecipitable PC12 cell NILE GP. The minor bands seen in Figure 11, lanes 2, 3, and 7 , may be due to proteolysis of CNS NILE-cross-reactive GP during preparation or alternatively to processing in situ prior to extraction. Immunoprecipitation analysis of 
actively contracting rat skeletal muscle cultures and $\mathrm{C} 6$ glioma cells did not reveal any synthesis of NILE GP (Table I).

\section{Discussion}

The PC12 line is a powerful model system for studying the mechanisms and consequences of neuronal differentiation and, in particular, the means by which NGF triggers the differentiation of target cells into mature neurons. Changes in PC12 cell composition which accompany NGF-induced neuronal differentiation are consequently of considerable interest. NILE glycoprotein is one of a restricted number of PC12 macromolecules affected by NGF treatment, and it has, therefore, been the focus of the present study.

A variety of observations indicated that the antisera were directed against NILE glycoprotein and were monospecific. The PC12 glycoprotein recognized by the antisera was identical to NILE GP in its electrophoretic mobility on SDS gels, sensitivity to trypsin, cell surface distribution, and degree of NGF induction. Using rocket immunoelectrophoresis, a single precipitate was obtained with carbohydrate-labeled PC12 cells. By SDS gel electrophoresis, a single band was immunoprecipitated from carbohydrate- and amino acid-labeled PC12 cultures.

Induction of NILE GP by NGF. Our studies indicate that the increased fucose labeling of NILE GP that occurs in PC12 cultures in response to NGF is, in fact, correlated with a selective increase in the specific levels of this glycoprotein. This increase seems to reach at least a 3-fold level. It is not known whether this increase reflects changes in synthesis and/or degradation. However, past studies have indicated that the increase in fucose labeling is selectively blocked by inhibitors of transcription (McGuire et al., 1978), implying that a synthetic component may be responsible for this effect.

Distribution of NILE GP. Material cross-reacting with NILE GP was found on most, if not all, of a wide variety of neurons cultured from the central and peripheral nervous systems, on cultured murine and human neuroblastomas, and on neurons in stretch preparations of iris and gut. Indirect immunofluorescence indicated, furthermore, that NILE GP cross-reactivity was distributed on somas, neurites, and growth cones. In contrast, the present and past (Lee et al., 1977, 1981) studies have indicated that NILE GP is not detectable on or synthesized by a wide variety of non-neuronal tissues and cells. Hence NILE GP seems to be a neuronal marker of widespread distribution in the nervous system.

NILE GP-cross-reacting material was also present on and synthesized in small amounts by cultured sympathetic ganglion Schwann cells. NILE GP does not seem, however, to be a general glial marker because it was not detected in cultured C6 glioma cells and glial filamentcontaining astroglia.

Molecular properties of NILE GP. Anti-NILE GP selectively immunoprecipitates two different molecular weight classes of cross-reactive glycoprotein: a $200,000-$ to 210,000-dalton macromolecule associated with CNSderived neurons (cerebellum, cerebral cortex, and spinal cord), and a 225,000 - to 230,000 -dalton glycoprotein expressed by cells of periphral nervous system origin (sym- pathetic and sensory neurons), PC12 cells, human and murine neuroblastoma cells, and Schwann cells. Combination of fucose-labeled PC12 cells and unlabeled cerebellar cultures prior to extraction did not alter the molecular weight of the labeled PC12 NILE GP. This suggests that the lower molecular weight, cross-reactive glycoprotein found in CNS cultures is not generated by an increase in or altered specificity of proteolytic activity associated with CNS cultures. Whether the apparent distinction between CNS and PNS NILE GP is due to a different apoprotein or to differential glycosylation of a common apoprotein is under investigation.

Possible relationship of NILE GP to other glycoproteins. Current studies reveal that NILE GP is produced by murine and human neuroblastoma lines. Glick and coworkers (Littauer et al., 1980) have reported a 200,000dalton glycoprotein which is found in higher levels on the neurites and surface membranes of differentiated, as compared with undifferentiated, neuroblastoma cells. In another study, antiserum to N18 neuroblastoma cells was used to identify a nervous system-specific glycoprotein, designated band 1 (Akeson and $\mathrm{Hsu}, 1978$ ), with a molecular weight in excess of 200,000 daltons. Like NILE GP (Richter-Landsberg et al., submitted for publication), both band 1 and the glycoprotein identified by Glick and co-workers are released into the culture medium. In addition, an antiserum (designated anti-NS-4) raised against cerebellar cells has been reported to precipitate two major glycoproteins, one with a molecular weight of 200,000 , from cerebral, cerebellar, and retinal lysates (Goridis et al., 1978; Rohrer and Schachner, 1980). It is conceivable that all or some of the above components described by others are chemically and immunologically related to NILE GP. A monoclonal antibody has been reported that recognizes a surface component of peripheral neurons and PC12 cells (Vulliamy et al., 1981). However, unlike anti-NILE GP, this antibody does not recognize CNS neurons.

Significance of NILE GP. The observation that immunoreactive NILE GP is widely distributed on the surface of central and peripheral neurons but not on a variety of other cell types, and that it is detectable in all four of the mammalian species tested thus far (rat, mouse, guinea pig, and human), suggests that NILE GP has been structurally conserved to a significant degree and may play a basic role in the development and maintenance of neuronal structure and/or function. Preliminary results indicate that anti-NILE GP IgG or F $\left(a b^{\prime}\right)_{2}$ fragments do not inhibit NGF-promoted neurite outgrowth (S. Salton, unpublished result), action potentials, or saxitoxin binding (S. Salton, B. Rudy, and B. Kirschenbaum, unpublished result) in PC12 cultures. Consequently, a variety of possible functions will have to be assayed.

Anti-NILE GP, with its broad range of neuronal specificities, may have several practical applications. For instance, it may be a useful probe for detecting presumptive neurons and studying their early development in vitro and in vivo. In addition, the complement-mediated cytotoxic action of anti-NILE GP could be used to selectively destroy neurons in cultured nervous tissue and to select and functionally screen PC12 cell mutants deficient in surface membrane NILE GP. 


\section{References}

Akeson, R., and W. C. Hsu (1978) Identification of a high molecular weight nervous system specific cell surface glycoprotein on murine neuroblastoma cells. Exp. Cell Res. 115: $367-377$.

Axelsen, N. H., J. Kroll, and B. Weeke, eds. (1973) A Manual of Quantitative Immunoelectrophoresis, Universitetsforlaget, Uslo.

Barondes, S. H., ed. (1976) Neuronal Recognition, Plenum Press, New York.

Bornstein, M. B. (1958) Reconstituted rat-tail collagen used as a substrate for tissue cultures on coverslips in Maximow slides and roller tubes. Lab. Invest. 7: 134-137.

Chamley, J. H., G. E. Mark, and G. Burnstock (1972) Sympathetic ganglia in culture. II. Accessory cells. Z. Zellforsch. 135: 315-327.

Christian, C. N., M. P. Daniels, H. Sugiyama, Z. Vogel, L. Jacques, and P. G. Nelson (1978) A factor from neurons increases the number of acetylcholine receptor aggregates on cultured muscle cells. Proc. Natl. Acad. Sci. U. S. A. 75: 40114015 .

Costa, M., R. Buffa, J. B. Furness, and E. Solcia (1980) Immunohistochemical localization of polypeptides in peripheral autonomic nerves using whole mount preparations. Histochemistry 65: 157-165.

Dichter, M. A. (1978) Rat cortical neurons in cell culture; culture methods, cell morphology, electrophysiology, and synapse formation. Brain Res. 149: 279-293.

Dichter, M. A., A. S. Tischler, and L. A. Greene (1977) Nerve growth factor-induced increase in electrical excitability and acetylcholine sensitivity of a rat pheochromocytoma cell line. Nature 268: 501-504.

Dulbecco, R., and M. Vogt (1954) Plaque formation and isolation of pure lines with poliomyelitis viruses. J. Exp. Med. 99: $167-182$

Feramisco, J. R., and S. H. Blose (1980) Distribution of fluorescently labeled alpha-actinin in living and fixed fibroblasts. J. Cell Biol. 86: 608-615.

Garrels, J. I., and D. Schubert (1979) Modulation of protein synthesis by nerve growth factor. J. Biol. Chem. 254: 79787985 .

Goldman, B. M., and G. Blobel (1978) Biogenesis of peroxisomes: Intracellular site of synthesis of catalase and uricase. Proc. Natl. Acad. Sci. U. S. A. 75: 5066-5070.

Goridis, C., M. A. Joher, M. Hirsch, and M. Schachner (1978) Cell surface proteins of cultured brain cells and their recognition by anti-cerebellum (anti-NS-4) antiserum. J. Neurochem. 31: 531-539.

Greene, L. A., and G. Rein (1977) Release, storage and uptake of catecholamines by a clonal cell line of nerve growth factor (NGF) responsive pheochromocytoma cells. Brain Res. 129: 247-263.

Greene, L. A., and G. Rein (1978) Short-term regulation of catecholamine synthesis in an NGF-responsive clonal line of rat pheochromocytoma cells. J. Neurochem. 30: 549-555.

Greene, L. $\Lambda$., and $\Lambda$. S. Tischler (1976) Establishment of a noradrenergic clonal line of rat adrenal pheochromocytoma cells which respond to nerve growth factor. Proc. Natl. Acad. Sci. U. S. A. 73: 2424-2428.

Hatten, M. E. (1981) Cell assembly patterns of embryonic mouse cerebellar cells on carbohydrate-derivatized polylysine culture substrata. J. Cell Biol. 89: 54-61.

Hatten, M. E., and R. K. Liem (1981) Astroglial cells provide a template for the positioning of developing cerebellar neurons in vitro. J. Cell Biol. 90: 622-630.

Hatten, M. E., and R. L. Sidman (1978) Cell reassociation behavior and lectin-induced agglutination of embryonic mouse cells from different brain regions. Exp. Cell Res. 113: $111-125$.

Laemmli, U. K. (1970) Cleavage of structural proteins during the assembly of the head of bacteriophage T4. Nature 227: 680-685.

Laskey, R. A., and A. D. Mills (1975) Quantitative film detection of ${ }^{3} \mathrm{H}$ and ${ }^{14} \mathrm{C}$ in polyacrylamide gels by fluorography. Eur. J. Biochem. 56: 335-341.

Lee, V., M. L. Shelanski, and L. A. Greene (1977) Specific neuronal and adrenal medullary antigens detected by antisera to clonal PC12 pheochromocytoma cells. Proc. Natl. Acad. Sci. U. S. A. 74: 5021-5025.

Lee, V. M., L. A. Greene, and M. L. Shelanski (1980a) Differential cytotoxic activities of antisera against nerve growth factor-treated and untreated clonal pheochromocytoma cells. Neuroscience 5: 1979-1987.

Lee, V. M., M. L. Shelanski, and L. A. Greene (1980b) Characterization of antisera raised against cultured rat sympathetic neurons. Neuroscience 5: 2239-2245.

Lee, V., L. A. Greene, and M. L. Shelanski (1981) Identification of neural and adrenal medullary surface membrane glycoproteins recognized by antisera to cultured rat sympathetic neurons and $\mathrm{PC} 12$ pheochromocytoma cells. Neuroscience 6: 2773-2786.

Levi Montalcini, R., and P. U. Angeletti (1963) Essential role of the nerve growth factor in the survival and maintenance of dissociated sensory and sympathetic embryonic nerve cells in vitro. Dev. Biol. 7: 653-659.

Littauer, U. Z., M. Y. Giovanni, and M. C. Glick (1980) A glycoprotein from neurites of differentiated neuroblastoma cells. J. Biol. Chem. 255: 5448-5453.

Lowry, O. H., N. J. Rosebrough, A. L. Farr, and R. J. Randall (1951) Protein measurement with the folin phenol reagent. J. Biol. Chem. 193: 265-275.

McGuire, J. C., L. A. Greene, and A. V. Furano (1978) NGF stimulates incorporation of fucose or glucosamine into an external glycoprotein in cultured rat PC12 pheochromocytoma cells. Cell 15: 357-365.

Mirsky, R., L. M. B. Wendon, P. Black, C. Stolkin, and D. Bray (1978) Tetanus toxin: A cell surface marker for neurones in culture. Brain Res. 148: 251-259.

Mobley, W. C., A. Schenker, and E. M. Shooter (1976) Characterization and isolation of a proteolytically modified nerve growth factor. Biochemistry 15: 5543-5551.

Moscona, A. A., ed. (1974) The Cell Surface in Development, John Wiley and Sons, New York.

Owen, P., and M. R. J. Salton (1975) Antigenic and enzymatic architecture of Micrococcus lysodeikticus membranes established by crossed immunoelectrophoresis. Proc. Natl. Acad. Sci. U. S. A. 72: 3711-3715.

Ransom, B. R., E. Neale, M. Henkart, P. N. Bullock, and P. G. Nelson (1977) Mouse spinal cord in cell culture. I. Morphology and intrinsic neuronal electrophysiologic properties. J. Neurophysiol. 40: 1132-1150.

Rohrer, H., and M. Schachner (1980) Surface proteins of cultured mouse cerebellar cells. J. Neurochem. 35: 792-803.

Rutishauser, U., and G. M. Edelman (1980) Effects of fasciculation on the outgrowth of neurites from spinal ganglia in culture. J. Cell Biol. 87: 370-378.

Sidman, R. L. (1974) Contact interactions among developing mammalian brain cells. In The Cell Surface in Development, A. A. Moscona, ed., pp. 221 253, John Wiley and Sons, New York.

Sternberger, L. A. (1979) Immunocytochemistry, John Wiley and Sons, New York.

Vulliamy, T., S. Rattray, and R. Mirsky (1981) Cell-surface antigen distinguishes sensory and autonomic peripheral neurones from central neurones. Nature 291: 418-420. 